\title{
Article \\ Study on the Effect of Ground Heat Storage by Solar Heat Using Numerical Simulation
}

\author{
Jin-Hwan Oh and Yujin Nam * \\ Received: 21 September 2015; Accepted: 24 November 2015; Published: 1 December 2015 \\ Academic Editor: Hossam A. Gabbar \\ Department of Architectural Engineering, Pusan National University, 2 Busandaehak-ro 63, Geomjeong-gu, \\ Busan 609-735, Korea; dumkin@naver.com \\ * Correspondence: namyujin@pusan.ac.kr; Tel.: +82-51-510-7652; Fax: +82-51-514-2230
}

\begin{abstract}
Recently, energy storage techniques using renewable energy efficiently have attracted considerable attention. However, there are several problems when using renewable energy. In the case of solar energy, the energy production time is different from the consumption time, and the use of geothermal energy has high investment costs. In order to solve these problems, it is essential to develop high-efficiency systems using both solar and geothermal energy simultaneously and efficiently. Thus, in this study, the performance of underground heat storage of solar energy was examined by simulation using models of underground heat transfer and heat exchange for the development of an integrated hybrid system exploiting both geothermal and solar energy. As a result, the heat extraction performance was determined to be up to $72.75 \mathrm{~W} / \mathrm{m}$. As a result, in Kagoshima, the most southern area in Korea, a case of six hour heat storage operation achieved the highest heat exchange rate of $72.75 \mathrm{~W} / \mathrm{m}$, which is approximately $105 \%$ higher than the case of operation without heat storage.
\end{abstract}

Keywords: heat storage; solar collector; heat extraction; simulation; geothermal

\section{Introduction}

Recently, technologies for saving energy and greenhouse gas reduction have attracted attention from people to prevent global warming. Issues of environmentally friendly architecture and energy saving techniques have also been raised. Currently there are various regulations on energy consumption in different countries all over the world. There are still difficulties in dealing with problems associated with increasing energy demand, especially those during peak electricity demand periods. To solve these problems, technologies enabling the application of new renewable energy have emerged. Of them, geothermal heat pumping systems, has been expected to realize an effective saving in heating and cooling energy because it can exploit the geothermal power that is stable all year round. However, the comparatively high cost associated with the installation of such facilities and limited sites suitable for such installation have slowed the propagation of such facilities. To avoid these obstacles, technology that increases system performance by integrating geothermal source with another heat source system or reduces the capacity of equipment to be installed has emerged as an alternative way to exploit geothermal energy. Besides, heat (thermal energy) storage systems can resolve the issues of temporal discrepancy between the demand and the supply of thermal energy. Ground heat pump systems have the merit of utilizing the relatively stable underground temperatures, however, during long-term heating operation, the underground temperature will gradually go down due to heat extraction from the ground and, as a result, the system performance also decreases. As the solution against this problem, hybrid systems with other heat source systems are suggested and used in the system building field. The use of solar heat could be good choice for 
heating dominant buildings. Generally, solar heat collection systems consist of a solar heat collector, thermal storage tank, and circulation pump. The solar heat collector is the essential equipment for the system, but a thermal storage tank is additionally required when there is the discrepancy between the energy collection time and use time. Although thermal storage tanks have the advantage of easy application, they require additional space and installation costs, which sometimes are not small. Therefore, in this research, an underground heat storage system using solar heat was developed without the thermal storage tank.

Recently, many researchers have studied systems for underground heat storage [1,2]. Wang and Qi [3] have conducted performance analysis of a heat pump system using underground heat storage of solar energy in residential buildings based on experimental data. The results found that the efficiency of the heat storage was over $70 \%$. They studied on suitable ratio between the tank volume and the area of solar collectors, which was found as $20-40 \mathrm{~L} / \mathrm{m}$ range. Seo et al. [4] conducted an analytical assessment of the performance factor of heat storage systems using solar heat collectors. It was found that the effect of the collector efficiency and heat loss factor on system performance was significant. Park and Kim [5] have identified the applicability of horizontal geothermal systems using heat storage in a greenhouse. Benli and Durmus [6] have used the heat storage system of a greenhouse and performed an analysis during the coldest month of a year. Their results revealed the diameter of pipe at over 1 inch $(25.4 \mathrm{~mm})$ with coefficient of performance (COP) of a ground source heat pump (GSHP) system ranging from 2.3 to 3.8. Jeong [7] have examined the static heat storage time of a slab heat storage air conditioning system by analyzing surveyed data and found that the optimal duration of heat storage should be about $7 \mathrm{~h}$.

In addition, research on the media of heat storage systems has been conducted. Vanhoudt et al. [8] have applied an aquifer heat storage system (ATES) in a hospital with a high energy demand level. They conducted an economic analysis based on experimental data obtained from 3 years of monitoring. They found a reduction of $71 \%$ in energy consumption compared to a gas boiler installation with a payback period of 8.4 years without any subsidy. The amount of annual cost savings was $€ 54,000$. Hesaraki et al. [9] have compared and reviewed the efficiency of each heat storage systems by examining the seasonal heat storage system literature. They found that seasonal thermal energy storage systems were more efficient for collective regional development than for single dwelling residences with a corresponding level of investment within $20 \%-30 \%$ per square meter of single dwelling residence. Bony and Citherlet [10] have developed a numerical model for analyzing heat storage sets in which phase change material (PCM) is used. After comparing their analysis results to data obtained from monitoring, they verified the feasibility of heat storage using PCM through an analytical and experimental approach. Miro et al. [11] showed that by-products from the potash industry are suitable for thermal energy storage materials through verification experiments. Tiari et al. [12] developed a finned heat pipe-assisted latent heat thermal storage system and analyzed the performance of the system through numerical modeling. As a result, it was confirmed that the natural convection could accelerate the charging and reduce the total charging time of approximately $30 \%$. Furthermore, Shabgard et al. [13] developed a thermal network model in order to examine the performance of a latent heat thermal energy storage system combined with heat pipes. The model used the phase change process, the heat transfer process and the melting-solidification process.

However, few studies have examined the application of geothermal energy for underground heat storage systems. In this study, in order to analyze the performance of an underground storage system with solar heat, numerical simulation was conducted using a ground heat transfer model, a heat exchanger model and a surface heat flux model. This paper is focused on the effect of heat storage rate on the ground heat exchange rate. 


\section{Methods}

\subsection{Overview of the Simulation}

In this study, a 3-dimensional (3D) simulation model was developed by applying a geothermal energy transference model considering phase changes (solid, liquid, gas) in the ground and heat exchanger developed in prior studies $[14,15]$ for accurate analysis of underground heat storage using a solar-geothermal hybrid system. Computation of ground surface heat-flux considering heat exchange around the ground surface and outer air was also carried out. The ground heat transfer model used theoretical calculations for the following: ground surface long wave radiation, short \& long wave radiation of the sun, convective heat transfer, and transference of the sensible \& latent heat based on the standard weather data $[16,17]$ of the past 10 year averages provided by the meteorological administration. These values were used to set boundary conditions for the model. To predict underground heat exchange rate, analytical code of FEFLOW (finite element subsurface flow) was used, which was designed to perform 3D numerical analysis based on the law of conservation of matter like mass, constitutive material, linear momentum, and energy etc. Analysis equations used in the simulation code, are as follows: the temperature of the circulating water in the U-tube was determined using the formula in Equation (1) which is a one-dimension advection-diffusion equation:

$$
\begin{gathered}
\frac{\partial T_{\mathrm{w}}}{\partial t}=\frac{\lambda_{\mathrm{w}}}{\rho_{\mathrm{w}} \mathcal{C}_{\mathrm{w}}} \frac{\partial^{2} T_{\mathrm{w}}}{\partial z^{2}}-U_{\mathrm{w}} \frac{\partial T_{\mathrm{w}}}{\partial z}+\frac{h P_{\mathrm{w}}}{\rho_{\mathrm{w}} C_{\mathrm{w}} A_{\mathrm{w}}}\left(T_{1}-T_{\mathrm{w}}\right) \\
h=N \frac{\lambda_{\mathrm{w}}}{r} \\
N=0.23 \operatorname{Re}^{0.8} \operatorname{Pr}^{n}
\end{gathered}
$$

Here, $N$ is 0.4 in heating mode and 0.3 in cooling mode. The heat flux delivered to the underground at the heat exchanger surface was calculated by using the following equation:

$$
Q=\left(T_{\mathrm{s}}-T_{\mathrm{w}, i}\right) /(1 / h A)
$$

In addition, the heat flux $(Q)$ of ground surface is calculated by the heat balance in Equation (5):

$$
Q=R_{\text {sol }}+R_{\text {sky }}-R_{\text {surf }}-H_{\text {surf }}+L_{\text {surf }}
$$

Details of the analytical model have been described in prior studies [14,15]. An overview of simulation conducted in this study is illustrated in Figure 1. The system consists of a geothermal heat pump system (for heating \& cooling) and a solar energy system (for underground heat storage). A simulation was carried out through the analysis model to predict the energy to be transferred from the solar collector to the underground heat storage.

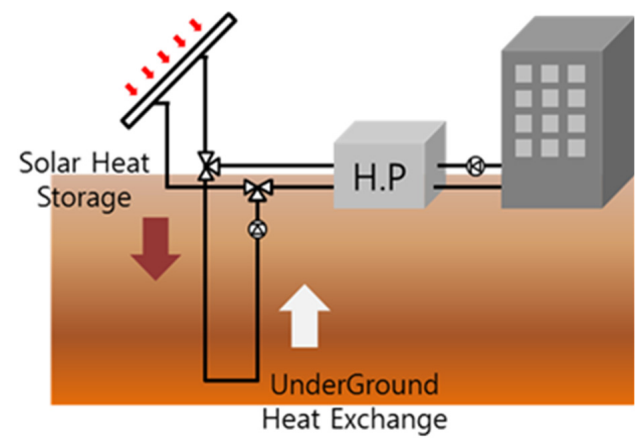

Figure 1. System concept. 


\subsection{Conditions of the Analysis}

The model used in this study to predict heat exchange rate and heat storage rate is shown in Figure 2. A tetra-mesh was used to improve the prediction accuracy. The number of meshes was set to 1413 in a slice and the total mesh number was set to 12,717. A model zone of $40 \mathrm{~m} \times 40 \mathrm{~m} \times 100 \mathrm{~m}$ was set to take influential coverage of underground heat transfer into account. In the center of the zone, a borehole with $0.2 \mathrm{~m}$ in diameter was inserted into a heat exchanger (U-tube, 32A, outer diameter: $32 \mathrm{~mm}$, inner diameter: $26 \mathrm{~mm}$ ). The gap between the borehole and inserted heat exchanger was filled with concrete. The ground was assumed to be granite. Values of thermal properties of the soil, grout, and U-tube are summarized in Table 1.

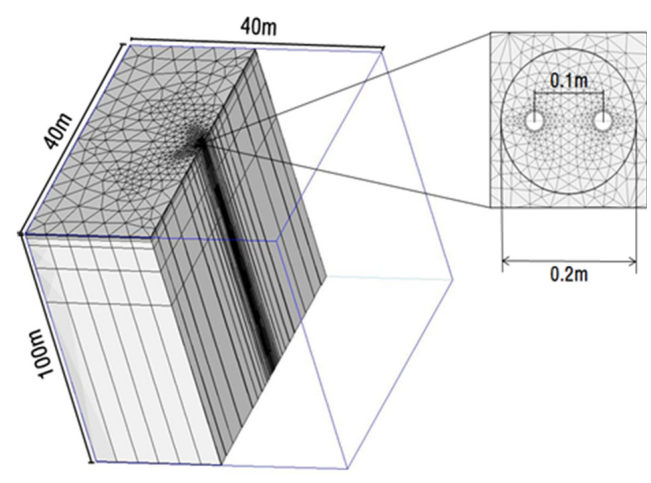

Figure 2. Simulation model.

Table 1. Thermal properties.

\begin{tabular}{cccc}
\hline Material & Porosity & Thermal conductivity $(\mathbf{W} / \mathbf{m K})$ & Heat capacity $\left(\mathbf{M J} / \mathbf{m}^{\mathbf{3}} \mathbf{K}\right)$ \\
\hline Granite & 0.10 & 3.50 & 2.92 \\
Concrete & 0.001 & 1.50 & 2.80 \\
U-tube & 0.58 & 0.41 & 2.38 \\
Water & - & 0.65 & 4.20 \\
\hline
\end{tabular}

The operation schedule is shown in Figure 3. The heat storage operation was set to collect heat and store heat. It was planned as follows: heat collection between 00:00 and 04:00, heat storage between 10:00 and 16:00, and heat collection again between 22:00 and 24:00. This was performed for one month in winter time (from December 1 to December 31). Conditions used for simulation are summarized in Table 2.

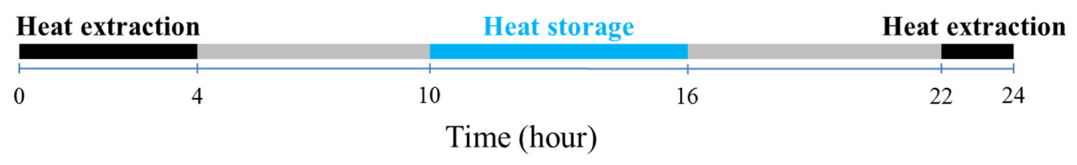

Figure 3. Operating schedule.

Table 2. Simulation conditions.

\begin{tabular}{ccc}
\hline Selection item & Heat storage mode & Heat extraction mode \\
\hline Operation conditions & Initial $\Delta T 10{ }^{\circ} \mathrm{C}$ limitation temperature $5{ }^{\circ} \mathrm{C}$ \\
Soil conditions & Granite $(\lambda: 3.5 \mathrm{~W} / \mathrm{mK})$ initial temperature $16{ }^{\circ} \mathrm{C}$ \\
Simulation period (day) & $12 / 1-12 / 31(1$ month) \\
Operation time $(\mathrm{h})$ & $10: 00-16: 00$ & $00: 00-04: 00 ; 22: 00-24: 00$ \\
\hline
\end{tabular}


Conditions employed for this case study are summarized in Table 3. The case study was designed to examine the influence of changes (weather conditions, square measure of solar energy collector, flow rate, heat storage duration, underground heat conductivity, and grout heat conductivity) on the process of heat collection from underground solar and geothermal energy heat storage. Case 2 with a solar collector and Case 1 without a solar collector were compared to each other to find the influence of underground heat storage of solar energy on heat collection performance. To identify the effect of differences in heat storage rate on heat collection performance, Case 4 with solar energy stored for $3 \mathrm{~h}$ and solar collector area of $30 \mathrm{~m}^{2}$, Case 5 with solar energy stored for $6 \mathrm{~h}$ and solar collector area of $30 \mathrm{~m}^{2}$, and Case 6 with solar energy stored for $6 \mathrm{~h}$ and solar collector area of $50 \mathrm{~m}^{2}$ were compared to each other. The influence of regional weather conditions on heat collection performance was also examined by comparing regions in Korea and Japan (Seoul, Busan, and Kagoshima). To find the effect of underground heat conductivity on heat collection performance, Cases 9-11 assigned with set value of $1.0 \mathrm{~W} / \mathrm{mK}, 1.5 \mathrm{~W} / \mathrm{mK}$, and $2.0 \mathrm{~W} / \mathrm{mK}$, respectively, were compared to Case 6 with assigned value of $1.5 \mathrm{~W} / \mathrm{mK}$. To determine the influence of grout heat conductivity on heat collection performance, Cases 12-14 with assigned value of $1.0 \mathrm{~W} / \mathrm{mK}, 2.0 \mathrm{~W} / \mathrm{mK}$, and $3.0 \mathrm{~W} / \mathrm{mK}$, respectively, were compared to Case 6 with assigned value of $1.5 \mathrm{~W} / \mathrm{mK}$. Heat collection efficiency of solar collector for underground heat storage (assumed to be about $60 \%$ ) was calculated using the Equation (6):

$$
\Delta T=\frac{Q \times A_{\mathrm{S}} \times 1000}{\pi r^{2} \times U \times C \times E}
$$

where $Q, A_{\mathrm{s}}, C, U, r$, and $E$ denoted the intensity of direct solar radiation $\left(\mathrm{W} / \mathrm{m}^{2}\right)$, the area of solar collector $\left(\mathrm{m}^{2}\right)$, the specific heat $\left(\mathrm{J} / \mathrm{kg} \cdot{ }^{\circ} \mathrm{C}\right)$, the flow rate $(\mathrm{m} / \mathrm{s})$, the radius of U-tube $(\mathrm{m})$, and the efficiency of solar energy collector, respectively. By using the $\Delta T$ calculated from Equation (1), the input of inlet temperature $\left(T_{\text {in }}\right)$ could be calculated using the Equation (7):

$$
T_{\text {in }}=T_{\text {out }}-\Delta T
$$

Table 3. Case conditions.

\begin{tabular}{ccccccc}
\hline Case & $\begin{array}{c}\text { Weather } \\
\text { condition }\end{array}$ & $\begin{array}{c}\text { Solar collector } \\
\text { size } \mathbf{( m}^{\mathbf{2}} \mathbf{n}\end{array}$ & $\begin{array}{c}\text { Flow rate } \\
\mathbf{( L / m i n )}\end{array}$ & $\begin{array}{c}\text { Soil thermal } \\
\text { conductivity } \\
\mathbf{( W / m K )}\end{array}$ & $\begin{array}{c}\text { Grout thermal } \\
\text { conductivity } \\
\mathbf{( W / m K )}\end{array}$ & $\begin{array}{c}\text { Heat storage } \\
\text { hour (h) }\end{array}$ \\
\hline 1 & Seoul & - & 9.30 & 3.50 & 1.5 & 3 \\
2 & Seoul & 20 & 9.30 & 3.50 & 1.5 & 3 \\
3 & Seoul & 20 & 13.95 & 3.50 & 1.5 & 3 \\
4 & Seoul & 30 & 13.95 & 3.50 & 1.5 & 3 \\
5 & Seoul & 30 & 13.95 & 3.50 & 1.5 & 6 \\
6 & Seoul & 50 & 13.95 & 3.50 & 1.5 & 6 \\
7 & Busan & 50 & 13.95 & 3.50 & 1.5 & 6 \\
8 & Kagoshima & 50 & 13.95 & 3.50 & 1.5 & 6 \\
9 & Seoul & 50 & 13.95 & 1.00 & 1.5 & 6 \\
10 & Seoul & 50 & 13.95 & 1.50 & 1.5 & 6 \\
11 & Seoul & 50 & 13.95 & 2.00 & 1.5 & 6 \\
12 & Seoul & 50 & 13.95 & 3.50 & 1.0 & 6 \\
13 & Seoul & 50 & 13.95 & 3.50 & 2.0 & 6 \\
14 & Seoul & 50 & 13.95 & 3.50 & 3.0 & 6 \\
\hline
\end{tabular}

\section{Results and Discussion}

Results of the analysis on heat collection performance of each case with or without the operation of underground heat storage are shown in Figures 4-7. Case 1 was operated with underground heat collection only. For Case 2, a $20 \mathrm{~m}^{2}$ solar collector was installed. In addition, the operation of 
heat accumulation and heat collection were conducted simultaneously for $3 \mathrm{~h}$. Daily average outlet temperature of circulation water during heat collection is shown in Figure 4.

Figure 4 shows the daily average outlet temperature of circulation water during heating operation in Cases 1 and 2. In Case 1, the ground temperature decreases during the heating operation, because only the heat extraction operation was conducted in this case. Therefore, the circulation water temperature seems to decrease gradually due to the drop of underground temperature. However, in Case 2, the operations of heat extraction and heat storage were conducted simultaneously, so the ground temperature increased with the underground heat storage with solar heat. Therefore, the circulation water temperature also increased with the increased underground temperature. Through this result, it is found that the underground heat storage using solar energy could improve the performance of the GSHP system.

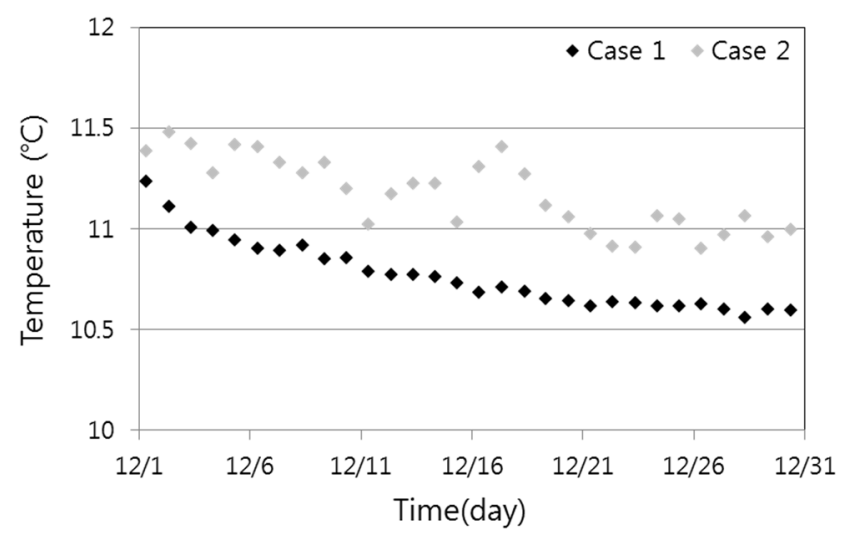

Figure 4. Daily average of heat source temperature (Cases 1 and 2).

The average outlet temperatures of the circulation water calculated at each unit length and heat exchange rate in heat collection are shown in Figure 5. The temperature of circulation water from the heat exchanger in Case 2 appeared to be higher than that in Case 1, proportional to the amount of solar radiation due to the effect of the heat storage operation. Case 2 stored solar energy through underground heat storage. It exhibited a heat collection performance approximately $11 \%$ higher than that in Case 1. The changes of heat exchange rate and circulation water temperature from the operation of heat collection are shown in Figures 6 and 7. Due to the underground heat storage of solar energy, the temperature of the circulation water was kept high, which greatly contributed to the improved performance of the heat collection operation.

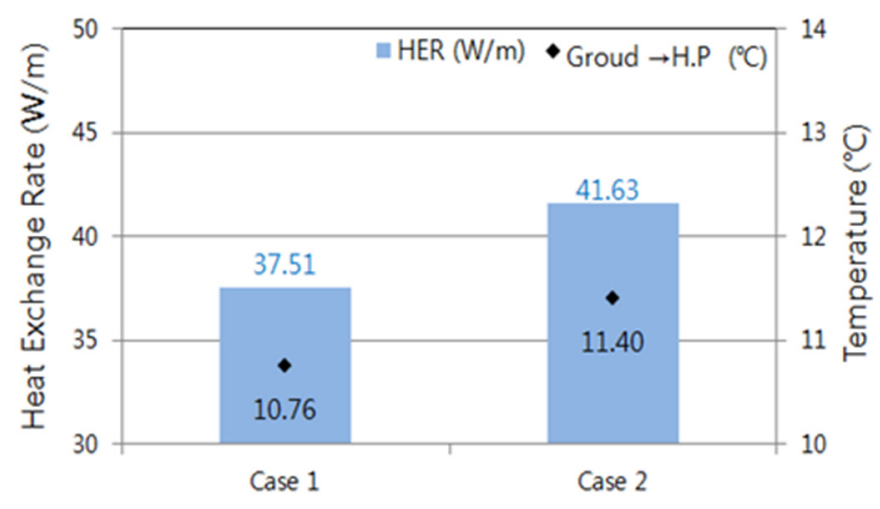

Figure 5. Average heat exchange rate (Cases 1 and 2). 


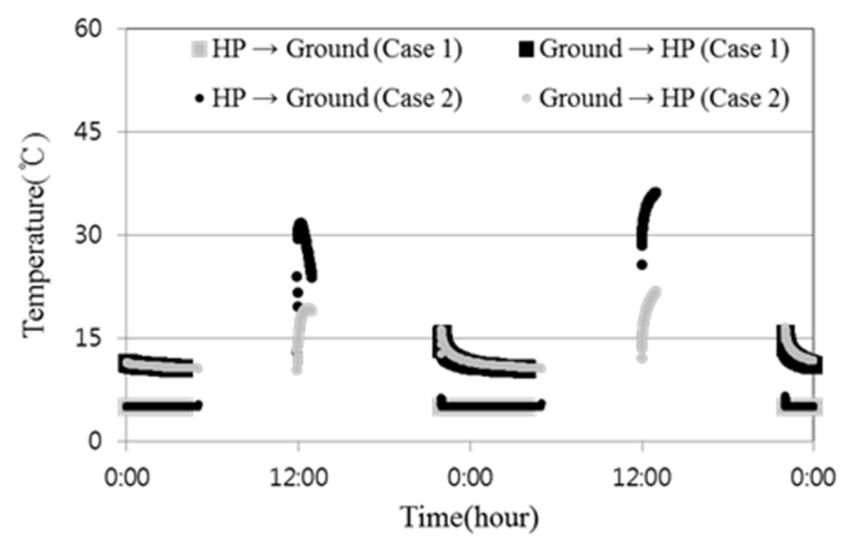

Figure 6. Operation of circulatory water temperature (Cases 1 and 2).

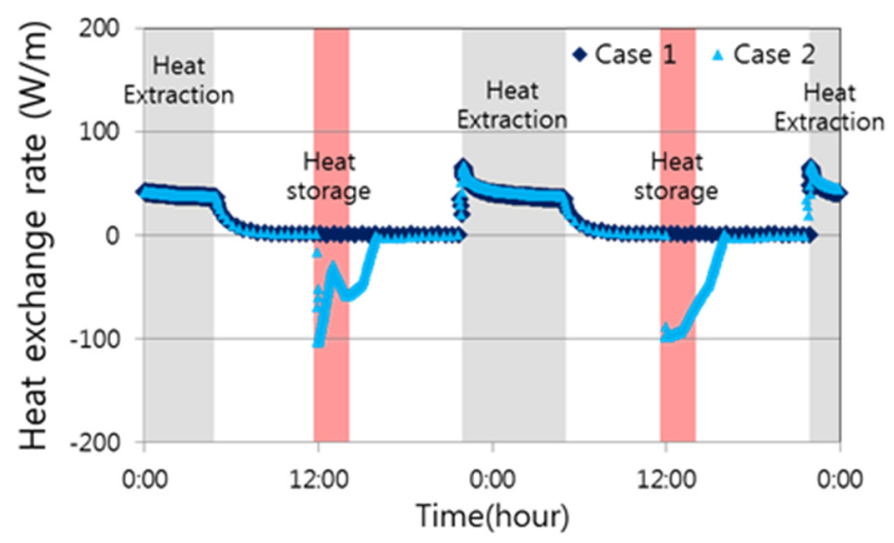

Figure 7. Operation of heat storage and heat exchange rate (Cases 1 and 2).

Results of the comparative analysis of heat storage rate and variation of circulation water are shown in Figures 8-10. The flow rate during underground heat storage was set at $9.30 \mathrm{~L} / \mathrm{min}$. However, for heat collection, the flow rates in Cases 2 and 3 were set at $9.30 \mathrm{~L} / \mathrm{min}$ and $13.95 \mathrm{~L} / \mathrm{min}$, respectively. The changes in heat storage rate and heat exchange rate in Cases 2 and 3 are shown in Figure 8.

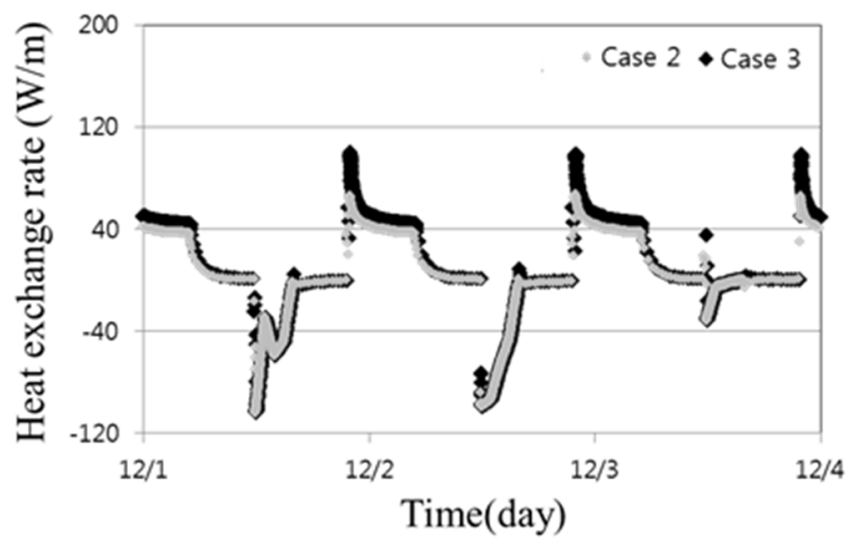

Figure 8. Operation of heat storage and heat exchange rate (Cases 2 and 3). 


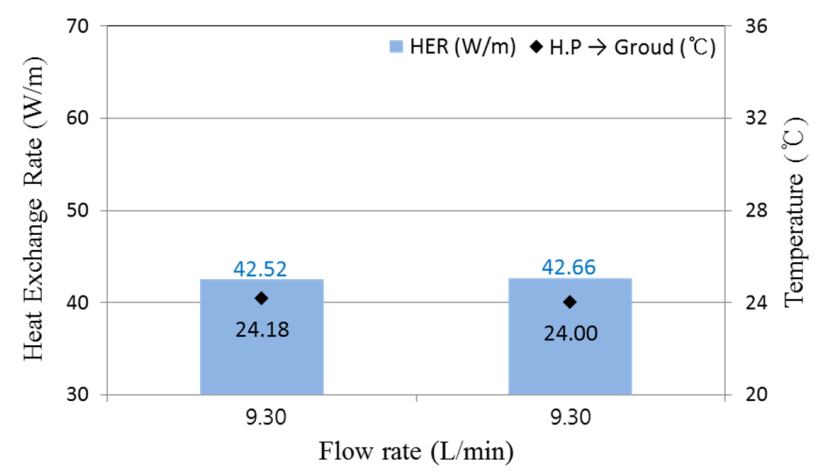

Figure 9. Average of heat storage rate for flow rate change (Cases 2 and 3).

The average inlet temperatures of circulation water calculated at each unit length and heat storage rate during underground heat storage are shown in Figure 9. The average outlet temperatures of circulation water calculated at each unit length and heat exchange rate during heat collection are shown in Figure 10. The results obtained from the analysis showed that the difference in heat storage rates between Cases 2 and 3 was insignificant. The heat exchange rate in Case 3 appeared to be approximately $19 \%$ bigger than that in Case 2 . The flow rate appeared to be proportional to the heat exchange rate level. However, the difference in the temperature of circulation water in heat exchangers between the two cases was only $1.33{ }^{\circ} \mathrm{C}$ (Case 2: $11.40^{\circ} \mathrm{C}$, Case 3: $10.07^{\circ} \mathrm{C}$ ). Thus, the value of flow rate in heat collection for follow-up cases was set at $0.483 \mathrm{~m} / \mathrm{s}$ for the simulation.

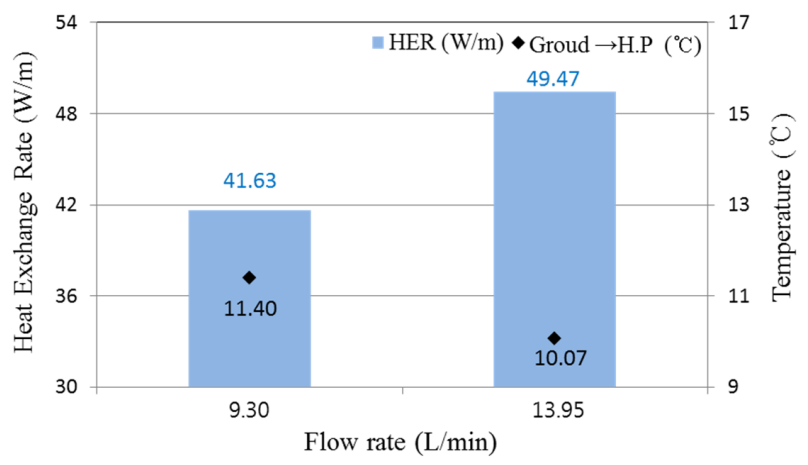

Figure 10. Average of heat exchange rate for flow rate change (Cases 2 and 3).

The comparisons between heat storage and heat collection performance according to the differences in the area of solar collector are illustrated in Figures 11 and 12.

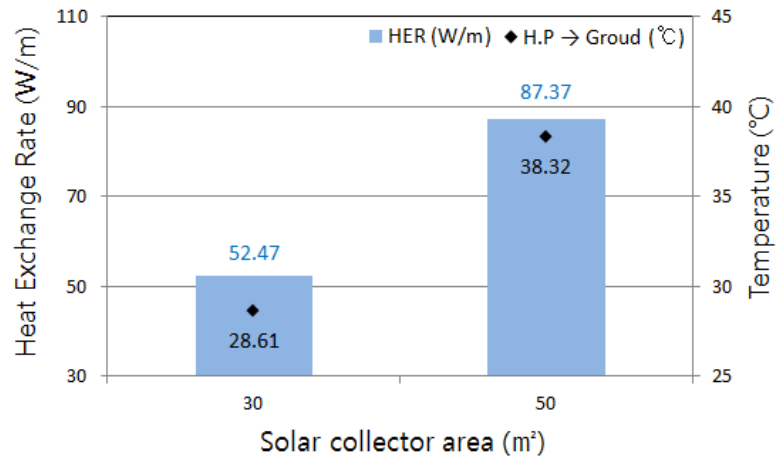

Figure 11. Average of heat storage rate for solar collector area change (Cases 5 and 6). 


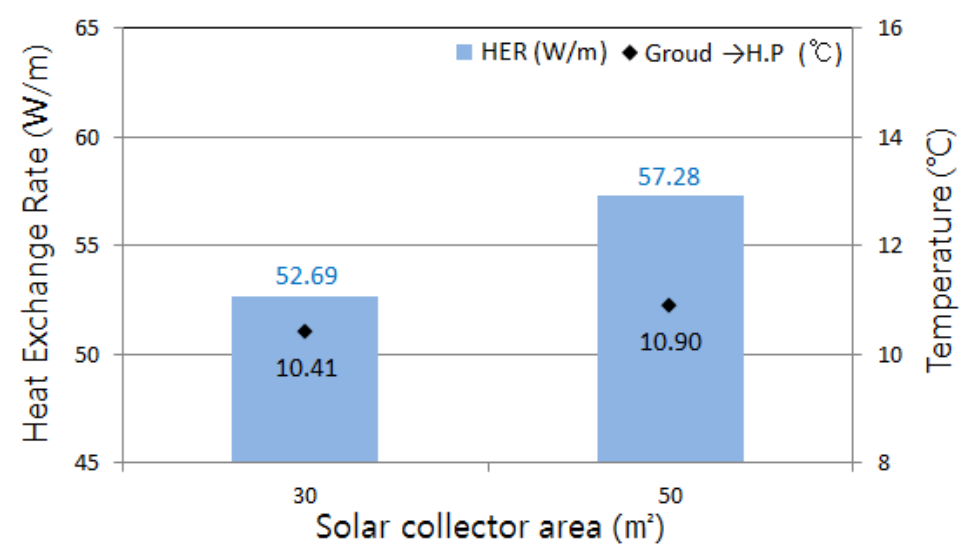

Figure 12. Average of heat exchange rate for solar collector area change (Cases 5 and 6).

To identify the influence of difference in heat storage rate on heat exchange rate, the heat collection performance was examined by setting each solar collector area in Cases 5 and 6 at $30 \mathrm{~m}^{2}$ and $50 \mathrm{~m}^{2}$, respectively. The average inlet temperatures of circulation water calculated at each unit length and heat storage rate during underground heat storage are shown in Figure 11. The average outlet temperatures of circulation water calculated at each unit length and heat exchange rate during heat collection are shown in Figure 12. Analysis of monthly average heat storage rate and heat exchange rate showed that the heat storage rate and heat exchange rate in Case 6 equipped with a bigger solar collector area were $67 \%$ and $9 \%$ higher than those in Case 5, respectively. Based on these results, the influence of stored heat on the heat collection performance was found to be smaller than that on heat storage. This could be due to heat loss during downtime between the completion of heat storage and the heat collection operation.

Results of the analysis on heat storage and heat collection performance in accordance with varied time of heat storage operation are shown in Figures 13-15. The operation of underground heat storage was continued for $3 \mathrm{~h}$ or $6 \mathrm{~h}$ (Case 4: 10:00-13:00, Case 5: 10:00-16:00). The average inlet temperatures of circulation water calculated at each unit length and heat storage rate during heat storage are shown in Figure 13. The average outlet temperatures of circulation water calculated at each unit length and heat exchange rate during heat collection are shown in Figure 14.

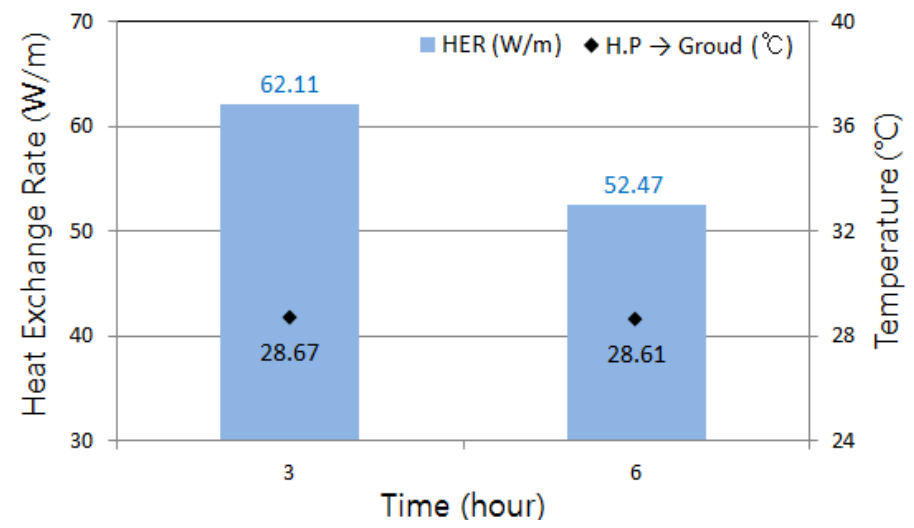

Figure 13. Average of heat storage rate for storage time change (Cases 4 and 5). 


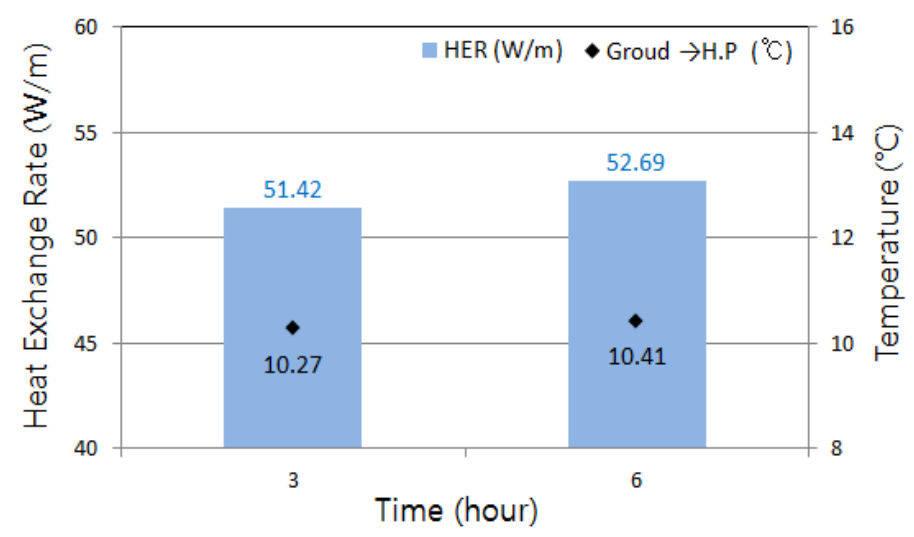

Figure 14. Average of heat exchange rate for storage time change (Cases 4 and 5).

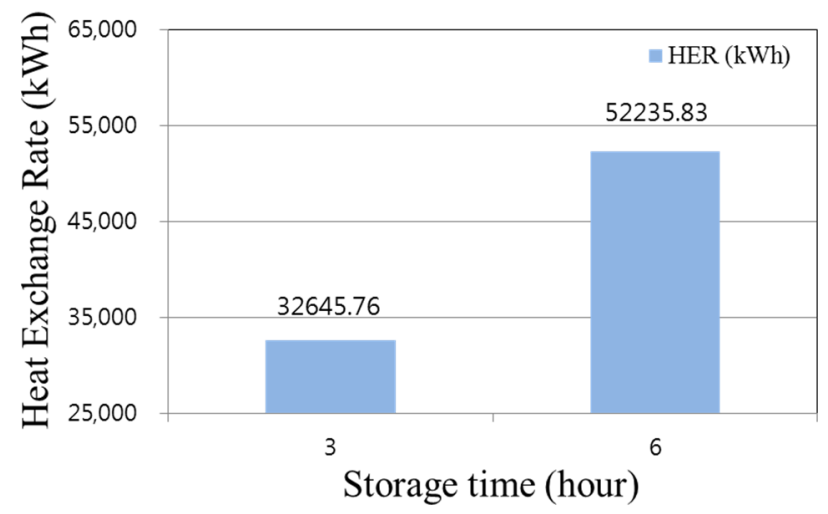

Figure 15. Daily average of heat storage rate for storage time change (Cases 4 and 5).

The daily average heat storage rates are shown in Figure 15. The average heat storage rate calculated at each unit length in Case 4 that stored heat for $3 \mathrm{~h}$ appeared to be $18 \%$ higher than that in Case 5 which stored heat for $6 \mathrm{~h}$. However, the total heat storage rate in Case 5 was about 1.6 times more than that in Case 4. The heat exchange rate in Case 5 also appeared to be slightly higher than that in Case 4. Such results could be attributed to the fact that less heat was lost and that more heat amount was accumulated due to higher heat storage rate in Case 5 despite the higher monthly average heat storage rate in Case 4 . Thus, the time for heat storage should be determined by taking the cost of power consumption of the heat storage of solar energy into account since the difference in the heat exchange performance in accordance with varied duration of heat storage operation was found to be insignificant.

The average outer air temperature and average amount of solar radiation in each region are shown in Figures 16-19. The weather data $[16,17]$ of the three regions in Korea and Japan (Seoul, Busan, and Kagoshima) represented in Cases 6-8 were referred to those of respective meteorological administrations in both countries. The respective regional conditions are summarized in Table 4. $T_{\mathrm{a}}, R_{\mathrm{s}}, T_{\text {soil }}$, and north latitude denote the annual mean temperature of outer air, monthly average amount of solar radiation, set underground temperature, and northern latitude, respectively. The monthly average temperature of outer air of each region is shown in Figure 16. The amount of solar radiation in each region is shown in Figure 17. 


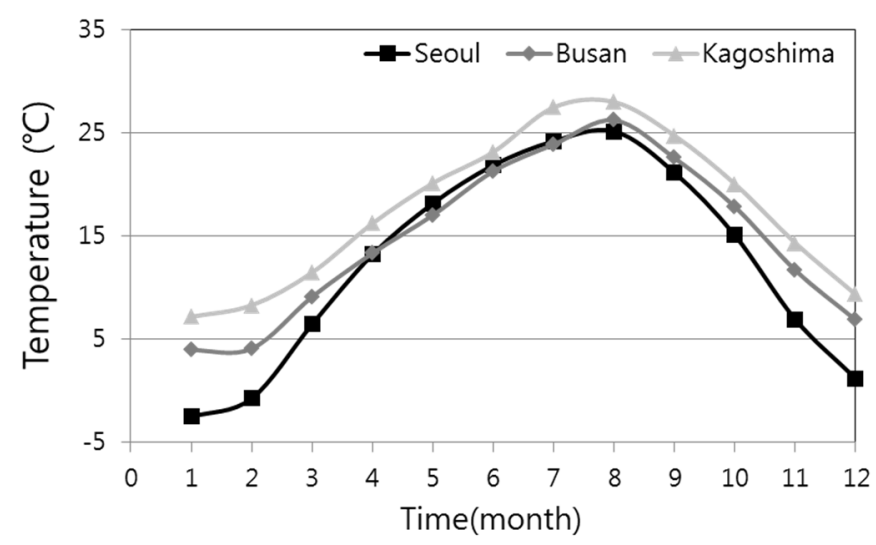

Figure 16. Monthly average air temperature (Seoul and Busan, Kagoshima).

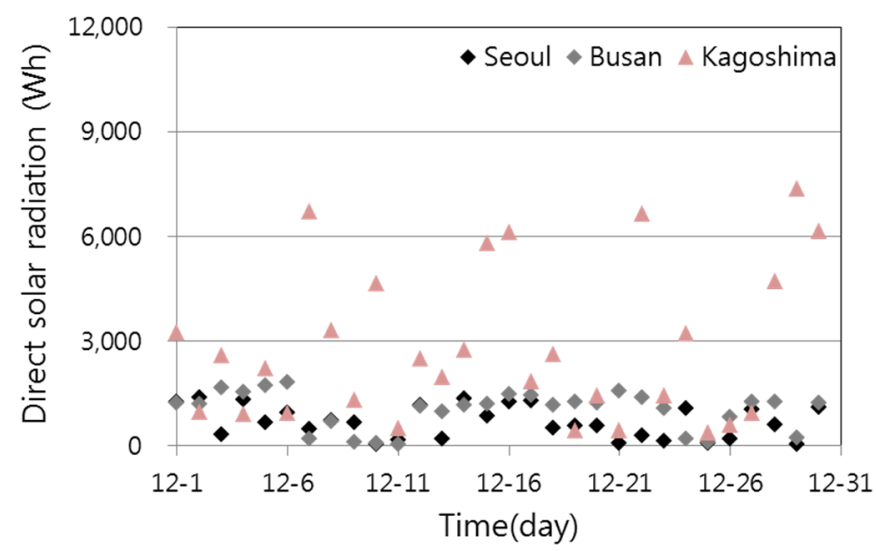

Figure 17. Daily total direct solar radiation (Seoul and Busan, Kagoshima).

Table 4. Simulation area conditions.

\begin{tabular}{ccccc}
\hline Location & $\boldsymbol{T}_{\mathbf{a}}\left({ }^{\circ} \mathbf{C}\right)$ & $\boldsymbol{R}_{\mathbf{s}}\left(\mathbf{W} / \mathbf{m}^{\mathbf{2}}\right)$ & $\boldsymbol{T}_{\text {Soil }}\left({ }^{\circ} \mathbf{C}\right)$ & North latitude $\left({ }^{\circ}\right)$ \\
\hline Seoul & 12.57 & 80.20 & 16 & $37^{\circ} 34^{\prime}$ \\
Busan & 14.87 & 99.36 & 16 & $35^{\circ} 06^{\prime}$ \\
Kagoshima & 17.52 & 116.06 & 16 & $31^{\circ} 33^{\prime}$ \\
\hline
\end{tabular}

The average inlet temperatures of circulation water calculated at each unit length and heat storage rate during heat storage are shown in Figure 18. The average outlet temperatures of circulation water calculated at each unit length and heat exchange rate during heat collection are shown in Figure 19. During heat storage, the average inlet temperatures of the heat exchanger were $38.32{ }^{\circ} \mathrm{C}$ in Seoul, $49.27{ }^{\circ} \mathrm{C}$ in Busan, and $65.89{ }^{\circ} \mathrm{C}$ in Kagoshima. The heat storage rate in Kagoshima had the highest value at $191.47 \mathrm{~W} / \mathrm{m}$, which was about $119 \%$ higher than the value in Seoul at $87.37 \mathrm{~W} / \mathrm{m}$.

The heat exchange rates during heating operation were $57.28 \mathrm{~W} / \mathrm{m}$ in Seoul, $62.93 \mathrm{~W} / \mathrm{m}$ in Busan, and $72.75 \mathrm{~W} / \mathrm{m}$ in Kagoshima. The results indicate that the potential of heat exchange rate is higher in the southern region due to higher annual average temperature of outer air and higher amount of solar radiation in the south compared to the north. The difference in average heat exchange rate between Seoul and Kagoshima was about 27\%, which was smaller than the value of $119 \%$ for the heat storage. 


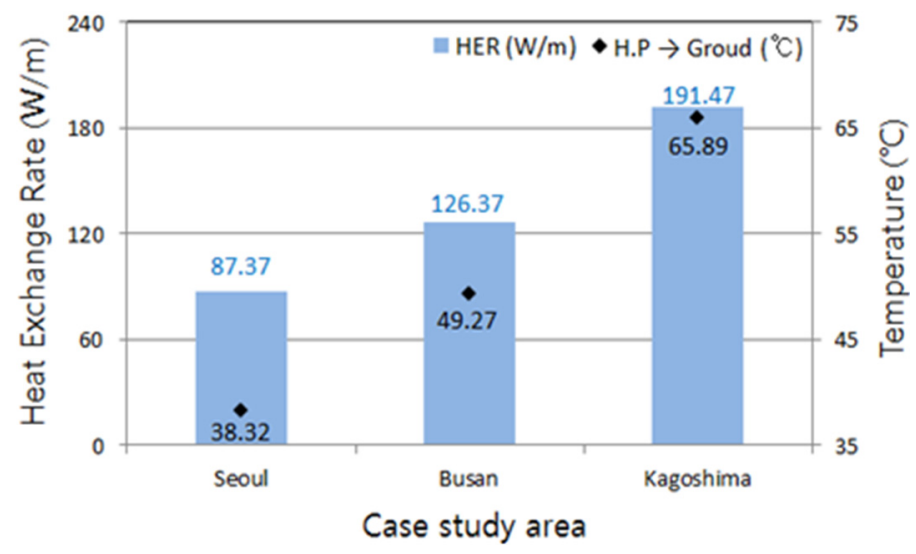

Figure 18. Average of heat storage rate for simulation area change (Seoul and Busan, Kagoshima).

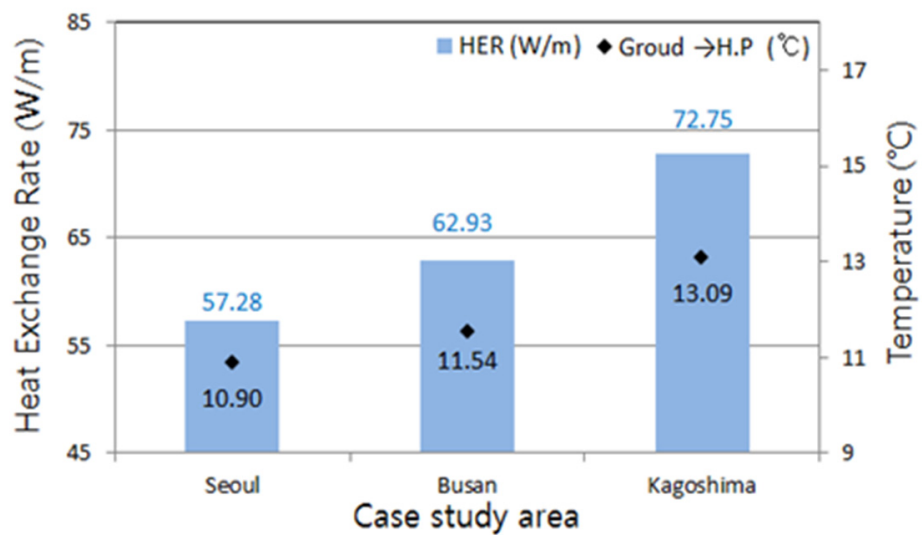

Figure 19. Average of heat exchange rate for simulation area change (Seoul and Busan, Kagoshima).

Results of the comparative analysis of heat collection performance according to different underground heat conductivity values are shown in Figures 20-22. In Cases 9-11, the values of underground heat conductivity were set at $1.0 \mathrm{~W} / \mathrm{mK}, 2.0 \mathrm{~W} / \mathrm{mK}$, and $3.0 \mathrm{~W} / \mathrm{mK}$, respectively, which were comparable to the value of Case 6 at $3.5 \mathrm{~W} / \mathrm{mK}$. The average inlet temperatures of circulation water calculated at each unit length and heat storage rate during heat storage operation are shown in Figure 20. The average outlet temperatures of circulation water calculated at each unit length and heat exchange rate in the heat collection operation are illustrated in Figure 21.

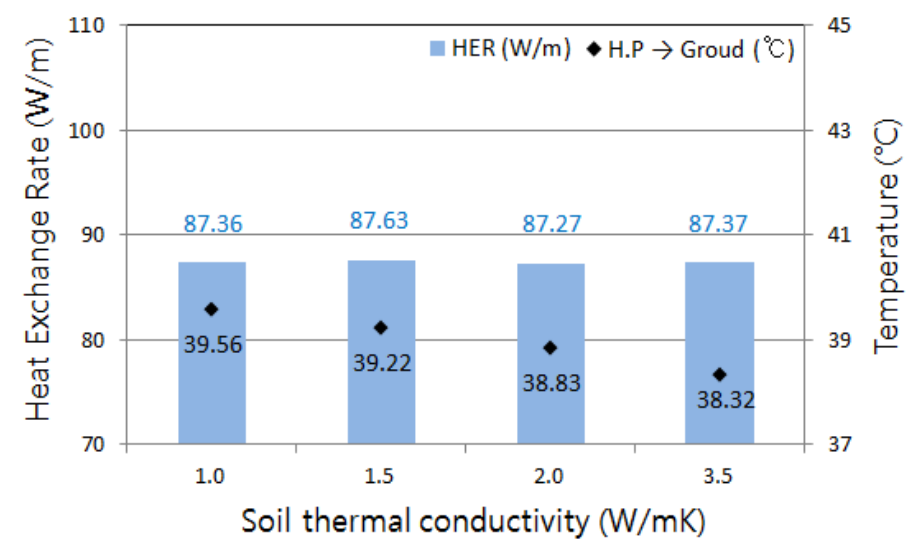

Figure 20. Average of heat storage rate for soil conductivity change (Cases 6 and 9-11). 


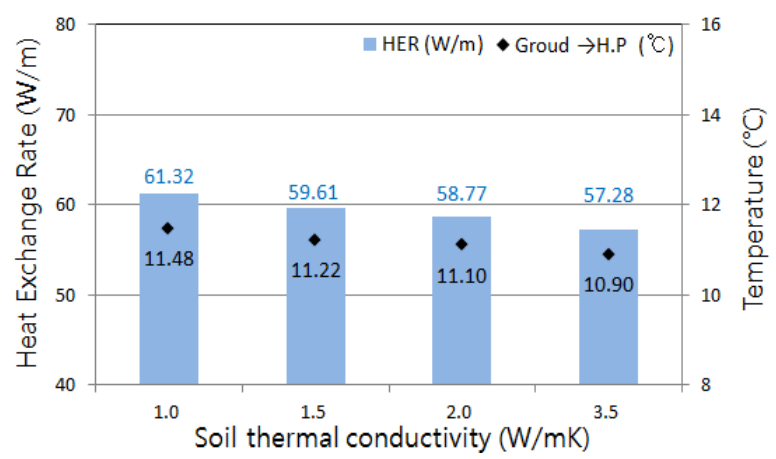

Figure 21. Average of heat exchange rate for soil conductivity change (Cases 6 and 9-11).

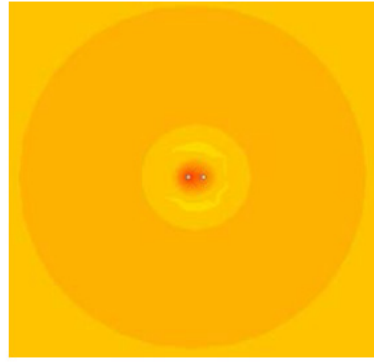

After the heat storage (Soil heat conductivity $=1.0 \mathrm{~W} / \mathrm{mK}$ )

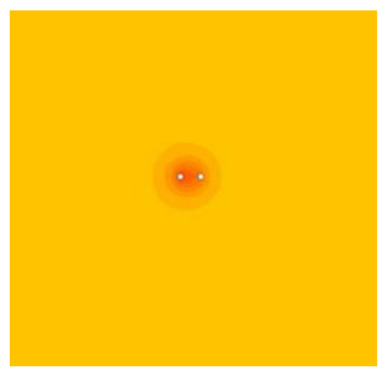

After the heat storage (Soil heat conductivity $=3.5 \mathrm{~W} / \mathrm{mK}$ )
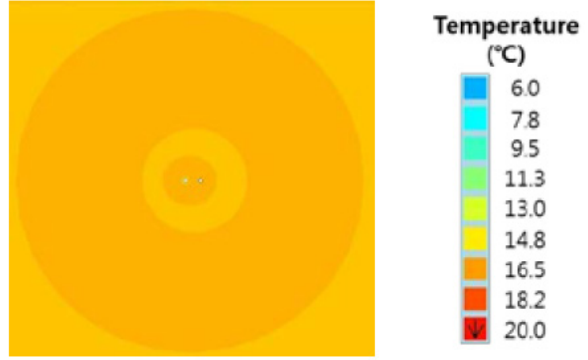

Before the heat extraction (Soil heat conductivity $=1.0 \mathrm{~W} / \mathrm{mK}$ )
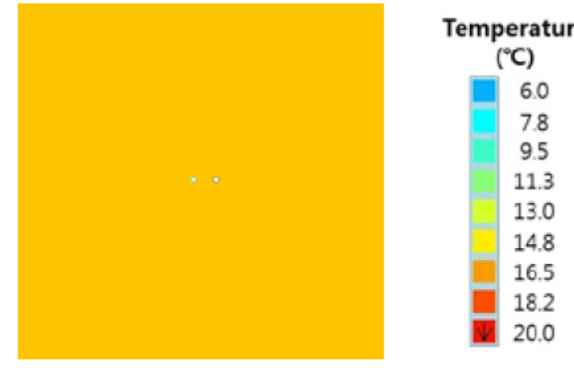

Before the heat extraction (Soil heat conductivity $=3.5 \mathrm{~W} / \mathrm{mK}$ )

Figure 22. Temperature distribution around the heat exchanger (Cases 6 and 9).

The difference in heat storage rate among heat storage cases (Cases 9-11) appeared to be insignificant. For heat collection cases, the values of heat exchange rate in Cases 9-11, and 6 were $61.32 \mathrm{~W} / \mathrm{m}, 59.61 \mathrm{~W} / \mathrm{m}, 58.77 \mathrm{~W} / \mathrm{m}$, and $57.28 \mathrm{~W} / \mathrm{m}$, respectively.

The maximum difference was about $7 \%$, attributable to the decreased value in accordance with increased underground heat conductivity. Results obtained from the analysis for conditions of $1.0 \mathrm{~W} / \mathrm{mK}$ and $3.5 \mathrm{~W} / \mathrm{mK}$ of underground heat conductivity are shown in Figure 22 . The temperature change around the heat exchanger situated $30 \mathrm{~m}$ beneath the ground was calculated right before and after the heat storage operation. For Case $9\left(\lambda_{\text {soil }}: 1.0 \mathrm{~W} / \mathrm{mK}\right)$, the underground temperature on the boundary surface of the borehole calculated right after the heat storage operation was $19.4^{\circ} \mathrm{C}$, similar to the value of $19.0^{\circ} \mathrm{C}$ in Case $6\left(\lambda_{\text {soil }}: 3.5 \mathrm{~W} / \mathrm{mK}\right)$. However, the underground temperature calculated right before the heat collection operation was $11.3^{\circ} \mathrm{C}$, revealing a rather bigger difference of $3.4^{\circ} \mathrm{C}$ compared to $7.9^{\circ} \mathrm{C}$ in Case 6 . From this result, it was identified that the heat accumulated through heat storage could be effectively collected through heat collection. However, the efficiency of heat collection varied greatly due to the different soil heat conductivity values. 
Results of the analysis for the performance of heat storage and heat collection with different grout heat conductivities are shown in Figures 23-27. For Cases 12-14, the grout heat conductivity was $1.0 \mathrm{~W} / \mathrm{mK}, 2.0 \mathrm{~W} / \mathrm{mK}$, and $3.0 \mathrm{~W} / \mathrm{mK}$, respectively, which was comparable to the grout heat conductivity at $1.5 \mathrm{~W} / \mathrm{mK}$ in Case 6 . The average inlet temperatures of circulation water calculated at each unit length and heat storage rate in the heat storage operation are shown in Figure 23. The average outlet temperatures of circulation water calculated at each unit length and heat exchange rate in the heat collection operation are shown in Figure 24.

The differences in heat storage rate in the respective operations of heat storage among cases appeared to be insignificant. The values of inlet temperatures of each heat exchanger in the cases were calculated as $41.01{ }^{\circ} \mathrm{C}, 38.32{ }^{\circ} \mathrm{C}, 36.72{ }^{\circ} \mathrm{C}$, and $35.40{ }^{\circ} \mathrm{C}$, respectively. The inlet temperature of each heat exchanger in the cases appeared to be inversely proportional to the level of grout heat conductivity. However, the heat exchange rate in each case of heat collection was $51.17 \mathrm{~W} / \mathrm{m}$, $57.28 \mathrm{~W} / \mathrm{m}, 61.16 \mathrm{~W} / \mathrm{m}$, and $65.67 \mathrm{~W} / \mathrm{m}$, respectively. And the heat collection performance appeared to be proportional to the level of grout heat conductivity.

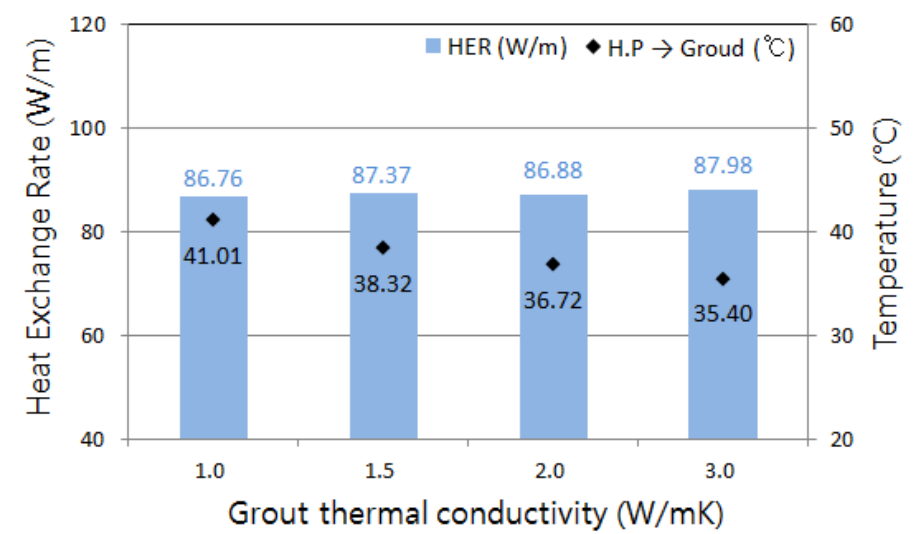

Figure 23. Average of heat storage rate for grout conductivity change (Cases 6 and 12-14).

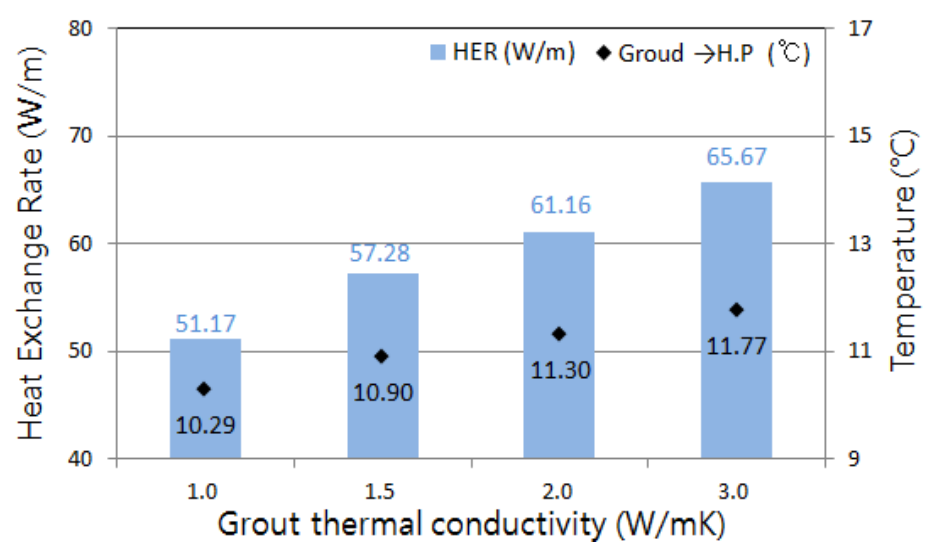

Figure 24. Average of heat exchange rate for grout conductivity change (Cases 6 and 12-14).

Analytical results of varied conditions of grout heat conductivity at $1.0 \mathrm{~W} / \mathrm{mK}$ and $3.0 \mathrm{~W} / \mathrm{mK}$ are shown in Figures 25 and 26. Temperature changes around the heat exchanger situated $30 \mathrm{~m}$ beneath the ground are presented. 


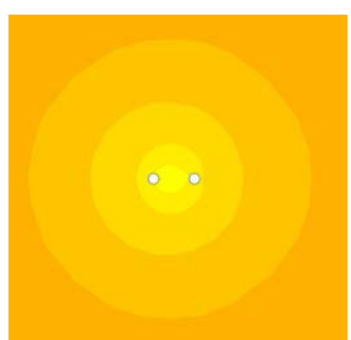

Before the heat storage (grout heat conductivity $=1.0 \mathrm{~W} / \mathrm{mK}$ )

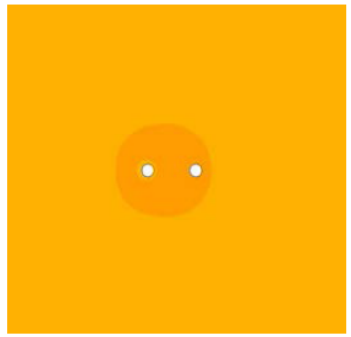

Before the heat extraction (grout heat conductivity $=1.0 \mathrm{~W} / \mathrm{mK}$ )

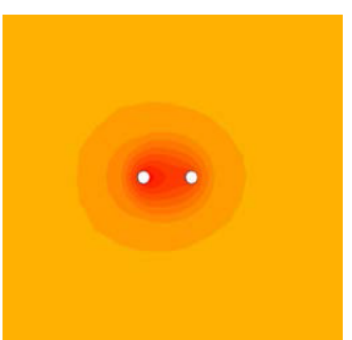

Temperature $\left({ }^{\circ} \mathrm{C}\right)$

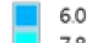

7.8

95

11.3

13.0

18.2
20.0

After the heat storage (grout heat conductivity $=1.0 \mathrm{~W} / \mathrm{mK}$ )

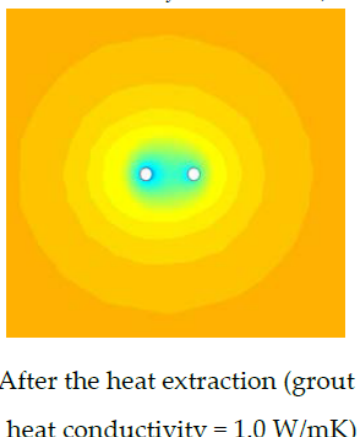

Temperature

heat conductivity $=1.0 \mathrm{~W} / \mathrm{mK}$ )

Figure 25. Temperature distribution around the heat exchanger (Case 12).

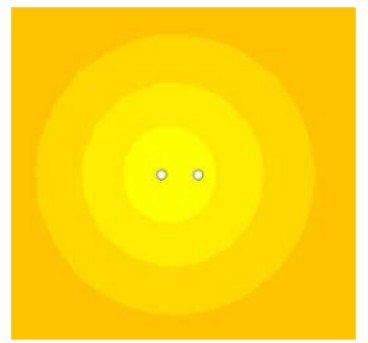

Before the heat storage (grout heat conductivity $=3.0 \mathrm{~W} / \mathrm{mK}$ )

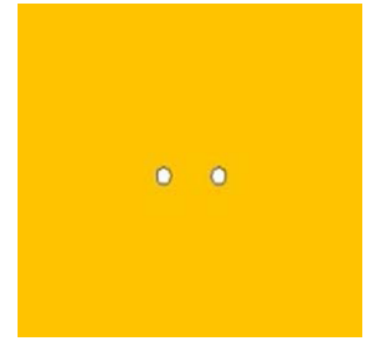

Before the heat extraction (grout heat conductivity $=3.0 \mathrm{~W} / \mathrm{mK}$ )

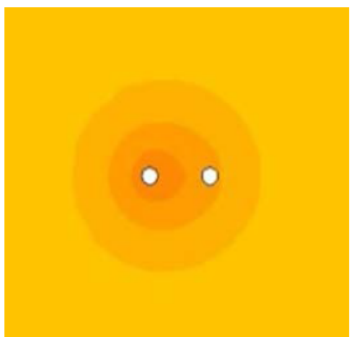

Temperature

After the heat storage (grout heat conductivity $=3.0 \mathrm{~W} / \mathrm{mK}$ )

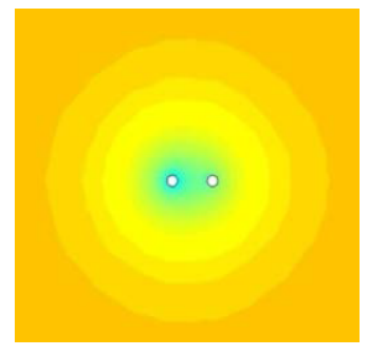

After the heat extraction (grout heat conductivity $=3.0 \mathrm{~W} / \mathrm{mK}$ )

Figure 26. Temperature distribution around the heat exchanger (Case 14).

The temperature changes around the heat exchanger calculated right before and after respective operations of heat storage and heat collection for Case $12\left(\lambda_{\text {grout }}=1.0 \mathrm{~W} / \mathrm{mK}\right)$ and Case 14 $\left(\lambda_{\text {grout }}=3.0 \mathrm{~W} / \mathrm{mK}\right)$ were determined to identify the influence of grout heat conductivity on the performance of heat storage and heat collection. As for Case $12\left(\lambda_{\text {grout }}=1.0 \mathrm{~W} / \mathrm{mK}\right)$, the temperature change right after heat storage influenced the temperature right before heat collection by borehole during heat storage because the low grout heat conductivity caused comparatively higher temperature around the borehole than that for Case $14\left(\lambda_{\text {grout }}=3.0 \mathrm{~W} / \mathrm{mK}\right)$. This was in consistent 
with our assumption at the beginning of the simulation that an excellent heat collection performance would be facilitated by heat stored in the borehole with low grout heat conductivity. However, the result obtained from heat collection performance analysis during heat collection revealed the higher level of heat collection performance was proportional to the level of grout heat conductivity, with a maximum difference at about $28 \%$. Contrary to the initial expectation, grout heat conductivity influenced heat collection with higher heat collection performance during the early stages of heat collection. However, it also manifested the decrease in efficiency in collecting peripheral heat, resulting in a rapid decrease in efficiency with time. Figure 27 indicates the heat exchange rate with time of the base case (Case 6).

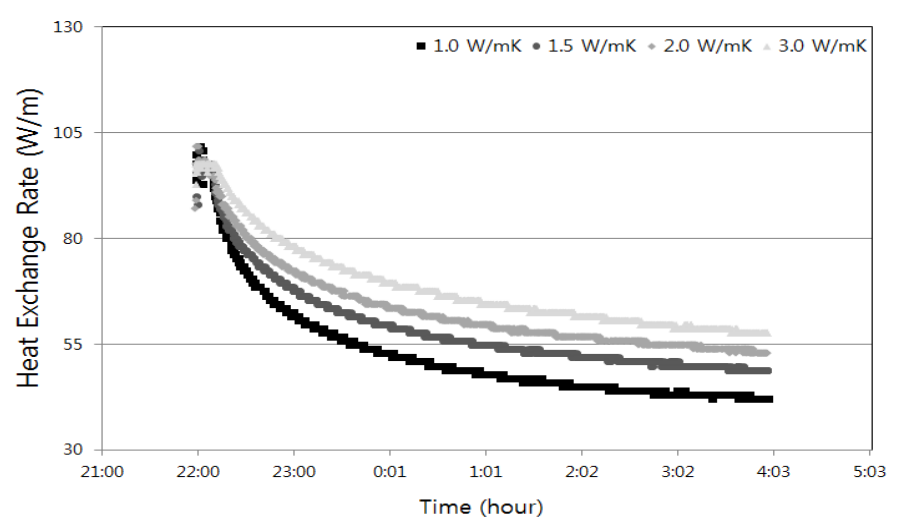

Figure 27. Fluctuation of heat exchange rate (Cases 12 and 14).

\section{Conclusions}

In this study, the performance of underground heat storage of solar energy was examined by simulation using models of underground heat transference and heat exchange for the development of integrated hybrid system exploiting geothermal and solar energy. Results obtained from the study are summarized in the Table 5.

Table 5. Simulation results. HER: heat exchange rate.

\begin{tabular}{ccccccccc}
\hline \multirow{3}{*}{ Case } & \multicolumn{3}{c}{ Heat storage } & \multicolumn{5}{c}{ Heat extraction } \\
\cline { 2 - 9 } & $\begin{array}{c}\boldsymbol{T}_{\text {inlet }} \\
\left({ }^{\circ} \mathbf{C}\right)\end{array}$ & $\begin{array}{c}\boldsymbol{T}_{\text {outlet }} \\
\left({ }^{\circ} \mathbf{C}\right)\end{array}$ & $\begin{array}{c}\Delta \boldsymbol{T} \\
\left({ }^{\circ} \mathbf{C}\right)\end{array}$ & $\begin{array}{c}\text { HER } \\
(\mathbf{W} / \mathbf{m})\end{array}$ & $\begin{array}{c}\boldsymbol{T}_{\text {inlet }} \\
\left({ }^{\circ} \mathbf{C}\right)\end{array}$ & $\begin{array}{c}\boldsymbol{T}_{\text {outlet }} \\
\left({ }^{\circ} \mathbf{C}\right)\end{array}$ & $\begin{array}{c}\Delta \boldsymbol{T} \\
\left({ }^{\circ} \mathbf{C}\right)\end{array}$ & $\begin{array}{c}\text { HER } \\
(\mathbf{W} / \mathbf{m})\end{array}$ \\
\hline 1 & - & - & - & - & 5.00 & 10.76 & 5.76 & 37.51 \\
2 & 23.61 & 16.32 & 7.30 & 47.52 & 5.01 & 11.17 & 6.15 & 40.83 \\
3 & 24.00 & 17.45 & 6.55 & 42.66 & 5.00 & 10.07 & 5.07 & 49.47 \\
4 & 28.67 & 19.13 & 9.54 & 62.11 & 5.01 & 10.27 & 5.26 & 51.42 \\
5 & 28.61 & 20.55 & 8.06 & 52.47 & 5.02 & 10.41 & 5.39 & 52.69 \\
6 & 38.32 & 24.90 & 13.42 & 87.37 & 5.04 & 10.90 & 5.86 & 57.28 \\
7 & 49.27 & 29.86 & 19.41 & 126.37 & 5.10 & 11.54 & 6.44 & 62.93 \\
8 & 65.89 & 36.48 & 29.41 & 191.47 & 5.64 & 13.09 & 7.45 & 72.75 \\
9 & 39.56 & 26.14 & 13.42 & 87.36 & 5.20 & 11.48 & 6.28 & 61.32 \\
10 & 39.22 & 25.77 & 13.46 & 87.63 & 5.11 & 11.22 & 6.10 & 59.61 \\
11 & 38.83 & 25.42 & 13.40 & 87.27 & 5.08 & 11.10 & 6.02 & 58.77 \\
12 & 41.01 & 27.68 & 13.32 & 86.76 & 5.05 & 10.29 & 5.24 & 51.17 \\
13 & 36.72 & 23.38 & 13.34 & 86.88 & 5.04 & 11.30 & 6.26 & 61.16 \\
14 & 35.40 & 21.89 & 13.51 & 87.98 & 5.04 & 11.77 & 6.72 & 65.67 \\
\hline
\end{tabular}

- The comparative case analysis revealed that the case with paralleled heat storage and underground heat collection (Case 2) had approximately $9 \%$ higher heat collection performance than the case using heat collection alone without heat storage (Case 1). 
- The effect of flow rate commonly set at $9.30 \mathrm{~L} / \mathrm{min}$ for heat storage and at $9.30 \mathrm{~L} / \mathrm{min}$ or $13.95 \mathrm{~L} / \mathrm{min}$ for heat collection was analyzed. Our results revealed that, although the difference in heat storage amount of solar energy was insignificant, about a $19 \%$ increase in underground heat exchange rate was found.

- The influence of varied square measure of solar collector was also examined by employing the conditions of $30 \mathrm{~m}^{2}$ and $50 \mathrm{~m}^{2}$ solar collector area. Our results revealed that the difference in the amount of solar energy collection was about $67 \%$ and the difference in underground heat exchange rate was about $9 \%$. Thus, the change in underground heat storage rate was not proportional to the change in heat collection performance.

- The effect of changes in the duration of heat storage operation was also analyzed by employing different conditions of the duration of underground heat storage operation for $3 \mathrm{~h}$ (Case 4 ) and for $6 \mathrm{~h}$ (Case 5). Result of the analysis showed the values of daily average heat storage rate were $32,645.76 \mathrm{kWh}$ for Case 4 and 52,235.83 kWh for Case 5. Therefore, the proportionality factor was about 1.6. However, the value of the underground heat exchange rate was $51.42 \mathrm{~W} / \mathrm{m}$ for Case 4 and $52.69 \mathrm{~W} / \mathrm{m}$ for Case 5, indicating an insignificant effect of different durations of operation on the underground heat collection performance. Thus, the operation of heat storage should take the cost of operation into account in determining the duration of operation which could have an insignificant effect on heat collection performance.

- The effect of varied weather conditions on heat collection performance was also examined by simulation of heat collection using different weather conditions corresponding to three regions (Seoul and Busan in Korea and Kagoshima in Japan). Results obtained from the analysis revealed the highest level of heat exchange rate occurred in Kagoshima, at about 119\% of that in Seoul. The level of annual average heat exchange rate in Kagoshima was about $27 \%$ higher than the other regions. Thus, southern regions with higher annual average outer air temperature and higher annual average amount of solar radiation might affect the performance of underground heat storage and heat collection thereof.

- The level of underground heat conductivity was identified to be inversely proportional to the level of heat collection performance via underground heat storage. This could be due to increased temperature of the area around the borehole where thermal diffusion was relatively retarded by the lower level of underground heat conductivity.

- The level of grout heat conductivity appeared to have no significant effect on heat storage performance. However, a higher level of grout heat conductivity could facilitate the enhancement of underground heat collection performance via underground heat storage. This is because low grout heat conductivity could enable efficient underground heat storage. However, low grout heat conductivity could be disadvantageous in collecting peripheral heat during heat collection.

Hence, further studies considering more factors such as borehole depth and the shape of heat exchangers should be carried out to develop an optimal design for this system. In addition, the cost of installation and operation thereof should be comprehensively evaluated.

Acknowledgments: This work was supported by the New \& Renewable Energy Core Technology Program of the Korea Institute of Energy Technology Evaluation and Planning (KETEP), granted financial resource from the Ministry of Trade, Industry \& Energy, Republic of Korea. (No. 20133030110900).

Author Contributions: All authors contributed equally to this work. All authors designed the simulations, discussed the results and implications and commented on the manuscript at all stages.

Conflicts of Interest: The authors declare no conflict of interest. 


\section{Nomenclature}

$T \quad$ Circulating water temperature $\left({ }^{\circ} \mathrm{C}\right)$

$\rho \quad$ Density $\left(\mathrm{kg} / \mathrm{m}^{3}\right)$

$U \quad$ Current speed $(\mathrm{m} / \mathrm{s})$

$P \quad$ Currency quantity $(\mathrm{L} / \mathrm{s})$

C Specific heat $\left(\mathrm{J} / \mathrm{kg}^{\circ} \mathrm{C}\right)$

A Area $\left(\mathrm{m}^{2}\right)$

$\mathrm{H} \quad$ Convective heat transfer rate $\left(\mathrm{J} / \mathrm{s} \mathrm{m}^{2 \circ} \mathrm{C}\right)$

$A_{\mathrm{s}} \quad$ Solar collector area $\left(\mathrm{m}^{2}\right)$

$Q \quad$ Direct solar radiation $\left(\mathrm{W} / \mathrm{m}^{2}\right)$

$r \quad$ U-tube radius $(\mathrm{m})$

E Solar collector efficiency

$T_{\text {in }} \quad$ Circulating water temperature (heat pump $\rightarrow$ ground)

$T_{\text {out }} \quad$ Circulating water temperature (ground $\rightarrow$ heat pump)

$R_{\text {sol }} \quad$ Total solar radiation

$R_{\text {sky }} \quad$ Downward atmospheric radiation

$R_{\text {surf }}$ Upward long wave radiation from the ground surface

$H_{\text {surf }}$ Sensible heat flux

$L_{\text {surf }} \quad$ Latent heat flux

\section{References}

1. Park, J.W.; Park, D.Y.; Choi, B.H.; Han, K.C. Review on thermal storage media for cavern thermal energy storage. J. Korean Soc. Rock Mech. 2012, 22, 243-256. [CrossRef]

2. Sanner, B.; Karytsas, C.; Mendrinos, D.; Rybach, L. Current status of ground source heat pumps and underground thermal energy storage in Europe. Geothermics 2003, 32, 579-588. [CrossRef]

3. Wang, H.; Qi, C. Performance study of underground thermal storage in a solar-ground coupled heat pump system for residential buildings. Energy Build. 2008, 40, 1278-1286. [CrossRef]

4. Suh, J.S.; Yi, C.S.; Yoon, J.H. Analysis of Thermal Performance of Solar Hot-Water and Heating System with Baffle Storage Tank. Korean J. Air Cond. Refrig. Eng. 2010, 22, 805-811.

5. Park, Y.J.; Kim, K.H. A Study on the Horizontal Ground Source Heat Pump Greenhouse Heating System with Thermal Storage Tank. J. Energy Eng. 2006, 15, 194-201.

6. Benli, H.; Durmus, A. Evaluation of ground-source heat pump combined latent heat storage system performance in greenhouse heating. Energy Build. 2009, 41, 220-228. [CrossRef]

7. Jung, J.H. Consideration of Appropriate Thermal Storage Time of Air-Conditioning System with Slab Thermal Storage in an Office Building by Use of Measurement Value. Korean J. Air Cond. Refrig. Eng. 2010, 22, 719-726.

8. Vanhoudt, D.; Desmedt, J.; Bael, J.V.; Robeyn, N.; Hoes, H. An aquifer thermal storage system in a Belgian hospital: Long-term experimental evaluation of energy and cost savings. Energy Build. 2011, 43, 3657-3665. [CrossRef]

9. Hesaraki, A.; Holmberg, S.; Haghighat, F. Seasonal thermal energy storage with heat pumps and low temperatures in building projects-A comparative review. Renew. Sustain. Energy Rev. 2015, 43, 1199-1213. [CrossRef]

10. Bony, J.; Citherlet, S. Numerical model and experimental validation of heat storage with phase change materials. Energy Build. 2007, 39, 1065-1072. [CrossRef]

11. Miro, L.; Navarro, E.; Suresh, P.; Gil, A.; Fernandez, A.L.; Cabeza, L.F. Experimental characterization of a solid industrial by-product as material for high temperature sensible thermal energy storage (TES). Appl. Energy 2014, 113, 1261-1268. [CrossRef]

12. Tiari, S.; Qiu, S.G.; Mahdavi, M.B. Numerical study of finned heat pipe-assisted thermal energy storage system with high temperature phase change material. Energy Convers. Manag. 2015, 89, 833-842. [CrossRef] 
13. Shabgard, H.; Bergman, T.L.; Sharifi, N.; Faghri, A. High temperature latent heat thermal energy storage using heat pipes. Int. J. Heat Mass Transfer 2010, 53, 2979-2988. [CrossRef]

14. Nam, Y.J.; Ooka, R.Z.; Hwang, S.H. Development of a numerical model to predict heat exchange rates for a ground-source heat pump system. Energy Build. 2008, 40, 2133-2140. [CrossRef]

15. Nam, Y.J. Numerical analysis for the Effect of Ground and Groundwater conditions on the Performance of Ground Source Heat Pump Systems. Korean J. Air Cond. Refrig. Eng. 2011, 23, 321-326. [CrossRef]

16. Korea Meteorological Administration. Available online: http://www.kma.go.kr (accessed on 31 August 2015).

17. Japan Meteorological Agency. Available online: http://www.jma.go.jp (accessed on 31 August 2015).

(C) 2015 by the authors; licensee MDPI, Basel, Switzerland. This article is an open access article distributed under the terms and conditions of the Creative Commons by Attribution (CC-BY) license (http:/ / creativecommons.org/licenses/by/4.0/). 